\title{
Amount of Squalene and Fatty Acid Composition of Triacylglycerols and Phospholipids in Flesh and Liver Lipids of Some Deep-sea Teleost Fish, Morid Cods and Whiptails
}

\author{
Kenji HaYashi * and Hideki KISHIMURA \\ Graduate School of Fisheries Sciences, Hokkaido University \\ (3-1-1, Minato-cho, Hakodate-shi, Hokkaido 041-8611, JAPAN)
}

Edited by I. Sugimoto, Nisshin OilliO Group, and accepted February 18, 2003 (received for review January 7, 2003)

\begin{abstract}
Examination was made of the amounts of squalene and fatty acid compositions of triacylglycerols (TG) and phospholipids (PL) in the flesh and liver lipids of five species of deep-sea teleost fish: the Pacific flatnose Antimora microlepis and the black mora Halargyreus johnsonii of morid cods and the roughscale rattail Coryphaenoides acrolepis, the pop-eye grenadier $C$. cinereus and the pectoral rattail $C$. pectoralis of whiptails. Liver specimens of these deep-sea teleost fish contained copious amounts of lipids (19.5-65.1\%) which were composed almost entirely of TG (72.6-95.9\%). Flesh samples contained small amounts of lipids $(0.3-$ $0.5 \%)$ with lower TG $(0.9-1.4 \%)$ and higher PL $(53.8-76.0 \%)$ content. In the livers and flesh, unsaponifiable matter from the neutral lipids comprised squalene $(42.4-57.7 \%$ and $3.7-$ $10.3 \%)$ and sterols $(22.8-51.0 \%$ and $84.0-95.3 \%)$, respectively, and the squalene content of liver lipids corresponded to $0.57-1.76 \%$. Component fatty acids in TG from liver lipids were characteristically rich in monoenes $(59.5-73.0 \%)$ with $22: 1 \mathrm{n}-11(15.7-24.1 \%), 18: 1 \mathrm{n}-9$ $(11.2-16.6 \%)$ and $20: 1 \mathrm{n}-11(8.7-10.9 \%)$ acids. Nevertheless, component fatty acids in PL from flesh lipids were rich in polyenes $(37.6-44.2 \%)$ with $22: 6 n-3(23.1-28.4 \%)$ and $20: 5 n-3$ $(8.7-8.8 \%)$ acids.
\end{abstract}

Key words: deep-sea teleost fish, morid cod and whiptail, flesh and liver, lipid, squalene, triacylglycerol, phospholipid, fatty acid

\section{Introduction}

Squalene, 2,6,10,15,19,23-hexamethyl-2,6,10,14,18,22tetracosahexaene, is found in many marine teleost fish in small quantities, and is now recognized as an intermediate in the biosynthesis of cholesterol (1). Nevertheless, the livers of certain deep-sea sharks are known to contain unusually large amounts of squalene (2-9). The reason why deep-sea sharks have large, oily livers with high levels of squalene is not exactly known, but it is believed that neutral buoyancy is part of the explanation because sharks do not have swim bladders (1).
It has been suggested that squalene has chemopreventive effects on radioprotection (10), on serum cholesterol (11) and on colon cancer (12). Squalene is an important raw material in cosmetics and pharmaceuticals, and is hydrogenated into squalane, which is used as a constituent of skin-care products in cosmetics and as a carrier of lipid-soluble drugs. The traditional source for squalene is primarily from deep-sea shark liver oils. Because of international concern for shark protection, attention has been focused on another potential source of squalene in olive oil (13), but the amounts of squalene in liver lipids of deep-sea teleost fish, morid

\footnotetext{
${ }^{*}$ Correspondence to: Kenji HAYASHI, Graduate School of Fisheries Sciences, Hokkaido University, 3-1-1, Minato-cho, Hakodate-shi, Hokkaido 041-8611, JAPAN

E-mail: hayashi@fish.hokudai.ac.jp
} 


\section{K. Hayashi and H. Kishimura}

cods and whiptails, which are untouched sources, are not reported.

On the other hand, in previous studies we observed that fatty acid composition of neutral lipids (NL), which were composed of abundant triacylglycerols (TG), in livers of the deep-sea teleost fish differed from those in fish living near the surface in having greater relative amounts of monoenoic fatty acids (14-17). The phenomenon was clearly recognized in fatty acids from liver NL, indicating the characteristic of fatty acid composition of tissue NL in deep-sea fish. Nevertheless, no other detailed study has been reported on fatty acid composition with monoenoic isomers of TG in tissue NL of the deep-sea teleost fish, morid cods and whiptails. Knowledge of the characteristics of fatty acid composition is essential to evaluate its potential use in fish oil industry.

The present study deals with the lipid and squalene levels in flesh and livers of five species of deep-sea teleost fish, morid cods and whiptails. The fatty acid compositions of TG and phospholipids (PL) classes in the tissue lipids of these fish were also determined.

\section{Experimental}

\section{$\mathbf{2} \cdot \mathbf{1}$ Materials}

Five species of deep-sea teleost fish: the Pacific flatnose Antimora microlepis and the black mora Halargyreus johnsonii of morid cods and the roughscale rattail Coryphaenoides acrolepis, the pop-eye grenadier $C$. cinereus and the pectoral rattail $C$. pectoralis of whiptails were caught from a trawler at a depth of $400 \mathrm{~m}$ at lat. $42^{\circ} 28^{\prime} \mathrm{N}$. and long. $143^{\circ} 57^{\prime} \mathrm{E}$. in the northwest Pacific Ocean in February 2000. The fish samples were kept frozen at $-20^{\circ} \mathrm{C}$ for a few months until analysis. The sizes of the fish examined were as follows: $39.5 \mathrm{~cm}$ total length, $348.4 \mathrm{~g}$ body weight and $19.7 \mathrm{~g}$ liver weight for A. microlepis $(\mathrm{n}=1), 36.3 \mathrm{~cm}$, $240.6 \mathrm{~g}$ and $1.7 \mathrm{~g}$ for $H$. johnsonii $(\mathrm{n}=1), 59.8 \pm 3.1$ (mean \pm standard deviation) $\mathrm{cm}, 899.6 \pm 165.5 \mathrm{~g}$ and $38.4 \pm 25.8 \mathrm{~g}$ for $C$. acrolepis $(\mathrm{n}=5), 44.2 \pm 6.0 \mathrm{~cm}$, $200.2 \pm 71.0 \mathrm{~g}$ and $5.0 \pm 2.5 \mathrm{~g}$ for $C$. cinereus $(\mathrm{n}=14)$, and $78.4 \pm 3.8 \mathrm{~cm}, 1512.1 \pm 279.1 \mathrm{~g}$ and $81.3 \pm 22.9 \mathrm{~g}$ for $C$. pectoralis $(\mathrm{n}=5)$, respectively. Liver specimens of H. microlepis, H. johnsonii, C. acrolepis and C. pectoralis were used individually for lipid extraction. Each of the pooled samples of flesh of $C$. acrolepis, $C$. cinereus and $C$. pectoralis and of livers of $C$. cinereus was also used for lipid extraction.

\section{$2 \cdot 2$ Extraction and Fractionation of Lipids}

Total lipids were extracted with a mixture of chloroform-methanol $(1: 2, \mathrm{vol} / \mathrm{vol})$ (18). NL were then separated from PL by means of chromatography on a silicic acid-Celite $545(2: 1, \mathrm{w} / \mathrm{w})$ column. The NL were eluted with chloroform and then the PL with methanol.

\section{$2 \cdot 3$ Thin-layer Chromatography (TLC)}

Qualitative and quantitative determination of the constituent lipids were carried out by TLC and a Iatroscan TH-10 instrument equipped with a flame ionization detector (Iatron Lab., Inc., Tokyo) with hexane-diethyl ether-acetic acid (80:20:1, vol/vol/vol) and hexanediethyl ether-formic acid (92:8:0.5, vol/vol/vol), respectively. TG from NL and squalene from unsaponifiable matter from NL were fractionated with hexane-diethyl ether-acetic acid (90:10:1, vol/vol/vol) and hexane, respectively. After development, the plates were sprayed with alcoholic rhodamine-6-GO as a visual reagent. Lipid constituents were identified by comparing the Rf-values with those of corresponding standards.

\section{2・4 Derivatization}

NL, TG and PL were subjected to alkaline hydrolysis in a $1 \mathrm{~N}$ ethanolic potassium hydroxide solution by boiling under reflux for $1 \mathrm{~h}$. The unsaponifiable matter from NL were extracted from the saponification mixture with diethyl ether. After acidification with dilute hydrochloric acid solution, fatty acids of TG and PL were recovered by diethyl ether extraction. Fatty acids were methylated with $14 \%$ boron trifluoride-methanol. Further purification of the derivatives was carried out by TLC.

\subsection{Gas-liquid Chromatography (GC)}

Squalene and fatty acid methyl esters were determined by GC in a Shimadzu GC14A gas chromatograph (Shimadzu Co. Ltd., Kyoto) equipped with a 30 $\mathrm{m} \times 0.25 \mathrm{~mm}$ I.D. Ulbon-HR-20M column (Shinwa Chemical Industries Ltd., Kyoto) and a flame ionization detector. The operating conditions were as follows: oven temperature was maintained at $230^{\circ} \mathrm{C}$ for the former and was maintained at $160^{\circ} \mathrm{C}$ for $5 \mathrm{~min}$; then the conditions were programmed to increase at $4{ }^{\circ} \mathrm{C} / \mathrm{min}$ to $230^{\circ} \mathrm{C}$ and subsequently to be maintained at $230^{\circ} \mathrm{C}$ for 
$30 \mathrm{~min}$ for the latter. Helium was the carrier gas. The peak area was integrated with a Shimadzu R-3A integrator.

Individual components of squalene and fatty acids were identified by comparing them with available known standards, as well as by comparing the relative retention times of fatty acid methyl esters of marine organisms (19).

\section{$2 \cdot 6$ GC-Mass Spectrometry (GC-MS)}

Squalene was identified by capillary GC-MS. The mass spectra were recorded with a JOEL JMS 700TZ mass spectrometer equipped with DB-17ht cross-linked 50\%-phenyl-methylpolysiloxane capillary column (30 $\mathrm{m} \times 0.25 \mathrm{~mm}$ I.D., J \& W Scientific) at $70 \mathrm{eV}$.

\section{Results and Discussion}

\section{$3 \cdot 1$ Identification of Squalene}

The Rf-values of squalene isolated from unsaponifiable matter from NL in tissue lipids of the deep-sea teleost fish examined were consistent on silicic acid plates with that of commercial squalene, 0.90 with the developing solvent of hexane-diethyl ether-acetic acid (90:10:1, vol/vol/vol) and 0.27 with hexane, respectively. By GC analysis, the chromatographically pure squalene isolated by preparative TLC from unsaponifiable matter from NL in tissue lipids had a single peak, and its retention time was the same as that of standard squalene, indicating that no homologs such as partially hydrogenated squalanes were present. Additionaly, mixture samples of squalene isolated from tissue lipids and standard squalene had a single peak on the GC chromatogram. Squalene isolated from tissue lipids was also identified by GC-MS. The characteristic mass peaks at $\mathrm{m} / \mathrm{z} 410$ (molecular ion: $\mathrm{M}^{+}, 13 \%$ ), $\mathrm{m} / \mathrm{z} 69$ $\left\{\mathrm{CH}_{3}\left(\mathrm{CH}_{3}\right) \mathrm{C}=\mathrm{CHCH}_{2^{-}}\right.$, base peak, $\left.100 \%\right\}, \mathrm{m} / \mathrm{z} 68\{-$ $\left.\mathrm{CH}_{2} \mathrm{C}\left(\mathrm{CH}_{3}\right) \mathrm{CHCH}_{2^{-}}, 33 \%\right\}, \mathrm{m} / \mathrm{z} 341\left(\mathrm{M}^{+}-69,20 \%\right)$, $\mathrm{m} / \mathrm{z} 273\left(\mathrm{M}^{+}-69-68,6 \%\right)$ and $\mathrm{m} / \mathrm{z} 205\left(\mathrm{M}^{+}-69-68-68\right.$, $10 \%)$, corresponding to bis-allylic cleavage from the unsaturated end of the chain, were observed. The mass fragmentation pattern of this compound was consistent with the observation of bacterial all-trans-squalene, as demonstrated by Kramer et al. (20).

\section{$3 \cdot 2$ Content and Composition of Lipids}

Table 1 shows the lipid content and class composition of flesh and livers from five species of deep-sea teleost fish: the Pacific flatnose A. microlepis and the black mora $H$. johnsonii of morid cods and the roughscale rattail $C$. acrolepis, the pop-eye grenadier $C$. ninereus and the pectoral rattail C. pectoralis of whiptails. The livers yielded $19.5-65.1 \%$ of lipids, being much higher than lipids from the flesh $(0.3-0.5 \%)$.

The liver lipid content of A. microlepis (42.5\%) of the morid cods examined and C. acrolepis $(45.3 \%), C$. cinereus $(41.6 \%)$ and $C$. pectoralis $(65.1 \%)$ of the whiptails examined were somewhat similar to those in the saffron cod Eleginus gracilis (35.3\%), the Pacific cod Gadus macrocephalus (45.9-54.0\%) and the walleye pollack Theragra chalcogramma $(42.5-46.2 \%)$ of cods, the brown hakeling Physiculus maximowiczi (57.1\%) and the forked hake Laemonema longipes (57.1-74.0\%) of morid cods, and C. pectoralis $(49.8 \%)$ of whiptails $(14,15,21-23)$. It was the characteristic of deep-sea teleost fish such as cods, morid cods and whiptails, whose livers stored copious amounts of lipids. Liver lipids of the deep-sea teleost fish examined consisted almost entirely of TG, ranging from $72.6 \%$ to $95.9 \%$. On the other hand, flesh lipids were composed almost entirely of PL $(53.8-76.0 \%)$ with small amounts of TG $(0.9-1.4 \%)$ (Table 1). The class compositions of liver lipids from the deep-sea teleost fish, A. microlepis and $H$. johnsonii of the morid cods examined and $C$. acrolepis, $C$. cinereus and $C$. pectoralis of the whiptails examined, which were rich in TG (72.6$95.9 \%$ ), were different from those in the L. longipes of morid cods, which were composed almost entirely of wax esters (71.5-87.4\%) (21-23).

The unsaponifiable matter isolated from liver NL of the deep-sea teleost fish examined accounted for 1.0$4.4 \%$, having much higher concentrations of squalene $(42.4-57.7 \%)$ and sterols $(22.8-51.0 \%)$. On the other hand, unsaponifiable matter from flesh NL accounted for $21.3-40.1 \%$, comprising predominantly sterols $(84.0-95.3 \%)$ (Table 1). Squalene levels in unsaponifiable matters isolated from liver NL of the deep-sea teleost fish examined corresponded to $0.57-$ $1.76 \%$ of the liver lipids. Squalene levels in liver lipids from $H$. johnsonii $(1.76 \%), C$. cinereus $(1.43 \%), C$. pectoralis $(0.86 \%)$ and C. acrolepis $(0.79 \%)$ were higher than those in the drumfish Sciaena hololepidota $(0.41 \%)$, the cape eel Congermuraena australis $(0.18 \%)$ and the angler fish Lophius pisatorius $(0.12 \%)$ (24) and in the herring Clupea harengus (0.01\%) (25), but not the eulachon Thaleichthys pacificus (4.2- 


\section{K. Hayashi and H. Kishimura}

Table 1 Content and Class Composition of Lipids from Flesh and Liver of Some Deep-sea Teleost Fish, Morid Cods and Whiptails.

\begin{tabular}{|c|c|c|c|c|c|c|c|c|}
\hline & \multicolumn{2}{|c|}{ Morid cods } & \multicolumn{6}{|c|}{ Whiptails } \\
\hline & \multirow{2}{*}{$\begin{array}{c}\text { Pacific flatnose } \\
\text { Antimora } \\
\text { microlepis } \\
\text { Liver }^{\mathrm{a})}\end{array}$} & \multirow{2}{*}{$\begin{array}{l}\text { Black mora } \\
\begin{array}{l}\text { Halargyreus } \\
\text { johnsonii }\end{array} \\
\text { Liver }^{\text {a) }}\end{array}$} & \multicolumn{2}{|c|}{$\begin{array}{l}\text { Roughscale rattail } \\
\text { Coryphaenoides } \\
\text { acrolepis }\end{array}$} & \multicolumn{2}{|c|}{$\begin{array}{l}\text { Pop-eye grenadier } \\
\text { C. cinereus }\end{array}$} & \multicolumn{2}{|c|}{$\begin{array}{l}\text { Pectoral rattail } \\
\text { C. pectoralis }\end{array}$} \\
\hline & & & Flesh $^{\text {b) }}$ & Liver $^{\mathrm{c})}$ & Flesh $^{\text {d) }}$ & Liver $^{\mathrm{e})}$ & Flesh $^{\text {b) }}$ & Liver $^{\mathrm{c})}$ \\
\hline Lipid content $\%$ f) & 42.5 & 19.5 & 0.5 & $45.3 \pm 5.3$ & 0.5 & 41.6 & 0.3 & $65.1 \pm 3.9$ \\
\hline \multicolumn{9}{|c|}{ Lipid component $\% \mathrm{~g}$ ) } \\
\hline Triacylglycerol & 95.9 & 78.7 & 0.9 & $84.2 \pm 3.1$ & 1.3 & 72.6 & 1.4 & $92.7 \pm 4.9$ \\
\hline Phospholipid & 1.9 & 5.7 & 61.0 & $4.3 \pm 1.1$ & 53.8 & 4.5 & 76.0 & $1.9 \pm 0.6$ \\
\hline Others $^{\text {h) }}$ & 2.2 & 15.6 & 38.1 & $11.5 \pm 3.1$ & 44.9 & 22.9 & 22.6 & $5.4 \pm 4.3$ \\
\hline USM \%i) & 1.0 & 4.4 & 25.9 & $1.9 \pm 0.5$ & 21.3 & 2.7 & 40.1 & $1.6 \pm 0.6$ \\
\hline \multicolumn{9}{|c|}{ USM component $\%$ i) } \\
\hline Squalene & 57.7 & 42.4 & 10.3 & $43.6 \pm 10.2$ & 7.7 & 55.6 & 3.7 & $54.5 \pm 4.3$ \\
\hline Sterol & 28.6 & 51.0 & 84.0 & $27.7 \pm 11.5$ & 93.6 & 30.6 & 95.3 & $22.8 \pm 6.7$ \\
\hline Glyceryl ether & 2.7 & 1.5 & 0.8 & $7.3 \pm 3.7$ & 1.6 & 5.6 & 0.4 & $12.3 \pm 1.8$ \\
\hline Others $^{\mathrm{k})}$ & 11.0 & 5.1 & 4.9 & $21.4 \pm 3.8$ & 1.1 & 8.2 & 0.6 & $10.4 \pm 1.7$ \\
\hline
\end{tabular}

\footnotetext{
a) Pooled samples $(n=1)$.

b) Pooled samples $(n=5)$.

c) Mean \pm standard deviation $(\mathrm{n}=5)$.

d) Pooled samples $(n=9)$.

e) Pooled samples $(n=14)$.

f) $\%$ to wet weight basis.

g) $\%$ to total lipid.

h) Consisted of squalene, free fatty acid, sterol and partial acylglycerol.

i) $\%$ to total lipid excluding phospholipid.

j) $\%$ to USM.

k) Consisted of alkenyl glyceryl ether and unknown polar compound.

USM: unsaponifiable matter.
}

$15.3 \%)(26)$ containing appreciable amounts of this compound in the liver lipids.

\section{$3 \cdot 3$ Composition of Fatty Acids}

Table 2 and Table 3 show the major fatty acid compositions of TG and PL from liver and flesh lipids of the deep-sea teleost fish: A. microlepis and H. johnsonii of morid cods and C. acrolepis, C. ninereus and C. pectoralis of whiptails, respectively. In the livers and flesh, each of 16:1, 18:1, 20:1 and 22:1 acids in monoenes in TG and PL composed their isomers. The relative high proportions of $16: 1 \mathrm{n}-7,18: 1 \mathrm{n}-9,18: 1 \mathrm{n}-7,20: 1 \mathrm{n}-11$, 20:1n-9, 22:1n-11 and 22:1n-9 isomers in each of 16:1, 18:1, 20:1 and 22:1 acids were determined, respectively. Generally, 22:1n-11 (15.7-24.1\%), 18:1n-9 (11.216.6\%), 20:1n-11 (8.7-10.9\%), 16:0 (7.5-12.2\%),
$16: 1 n-7(5.9-8.1 \%), 20: 1 n-9(4.2-6.7 \%)$ and $22: 6 n-3$ $(3.0-8.5 \%)$ acids in TG of the livers and 16:0 (27.8$30.3 \%), 22: 6 n-3$ (23.1-28.4\%), 18:1n-9 (8.4-10.5\%), $20: 5 n-3(8.7-8.8 \%)$ and $18: 0(5.7-6.7 \%)$ acids in the PL of the flesh were characteristic.

Differences in percentages of the component fatty acids were found between TG class in the livers and PL class in the flesh of the deep-sea teleost fish examined (Table $\mathbf{2}$ and Table 3, respectively). The fatty acid composition of TG in the livers was different from those of PL in the flesh; the former tending to be more monoenoic (mean: 68.6\%) with 22:1n-11 (20.1\%), 18:1n-9 (13.7\%), 20:1n-11 (10.2\%), 16:1n-7 (6.9\%) and $20: 1 n-9(5.8 \%)$ acids, and the latter tending to be more polyenoic $(40.5 \%)$ with $22: 6 n-3(25.0 \%)$ and 20:5n-3 (8.8\%) acids. 
Table 2 Fatty Acid Composition of Triacylglycerols and Phospholipids in Liver Lipids of Some Deep-sea Teleost Fish, Morid Cods and Whiptails.

$(\%)$

\begin{tabular}{|c|c|c|c|c|c|c|c|c|c|c|}
\hline & \multicolumn{4}{|c|}{ Morid cods } & \multicolumn{6}{|c|}{ Whiptails } \\
\hline & \multicolumn{2}{|c|}{$\begin{array}{c}\text { Pacific flatnose } \\
\text { Antimora } \\
\text { microlepis }\end{array}$} & \multicolumn{2}{|c|}{$\begin{array}{l}\text { Black mora } \\
\text { Halargyreus } \\
\text { johnsonii }\end{array}$} & \multicolumn{2}{|c|}{$\begin{array}{l}\text { Roughscale rattail } \\
\text { Coryphaenoides } \\
\text { acrolepis }\end{array}$} & \multicolumn{2}{|c|}{$\begin{array}{l}\text { Pop-eye grenadier } \\
\text { C. cinereus }\end{array}$} & \multicolumn{2}{|c|}{$\begin{array}{l}\text { Pectoral rattail } \\
\text { C. pectoralis }\end{array}$} \\
\hline & $\mathrm{TG}^{\mathrm{a})}$ & $\mathrm{PL}^{\mathrm{a})}$ & $\mathrm{TG}^{\mathrm{a})}$ & $\mathrm{PL}^{\mathrm{a})}$ & $\mathrm{TG}^{\mathrm{b})}$ & $\mathrm{PL}^{\mathrm{b})}$ & $\mathrm{TG}^{\mathrm{c})}$ & $\mathrm{PL}^{\mathrm{c})}$ & $\mathrm{TG}^{\mathrm{b})}$ & $\mathrm{PL}^{\mathrm{d})}$ \\
\hline $14: 0$ & 3.6 & 13.6 & 4.4 & 10.4 & 2.7 & 11.3 & 3.0 & 10.7 & 2.5 & 12.2 \\
\hline $16: 0$ & 9.8 & 36.9 & 12.2 & 31.2 & 7.5 & 22.8 & 7.8 & 24.2 & 7.9 & 26.8 \\
\hline $18: 0$ & 1.3 & 4.5 & 1.3 & 4.7 & 1.2 & 3.1 & 1.3 & 5.3 & 1.2 & 4.4 \\
\hline $16: \ln -9$ & 0.2 & 1.2 & 0.2 & 1.1 & 0.2 & 1.8 & 0.2 & 0.8 & 0.2 & 3.8 \\
\hline $16: 1 \mathrm{n}-7$ & 5.9 & 7.8 & 6.6 & 7.9 & 6.7 & 14.6 & 8.1 & 9.9 & 7.4 & 11.0 \\
\hline $18: 1 n-9$ & 13.5 & 8.3 & 12.8 & 11.4 & 14.2 & 14.0 & 11.2 & 9.6 & 16.6 & 10.5 \\
\hline $18: \ln -7$ & 3.2 & 2.6 & 2.8 & 3.5 & 4.1 & 4.4 & 4.8 & 4.2 & 4.3 & 2.4 \\
\hline $20: 1 n-11$ & 10.8 & 4.2 & 10.5 & 5.6 & 10.9 & 4.8 & 10.3 & 6.2 & 8.7 & 3.2 \\
\hline $20: 1 n-9$ & 4.2 & 1.9 & 6.1 & 3.1 & 6.7 & 2.5 & 5.2 & 2.4 & 6.6 & 1.4 \\
\hline $22: 1 n-11$ & 15.7 & 3.9 & 24.1 & 6.8 & 21.8 & 4.3 & 20.8 & 8.9 & 17.9 & 1.8 \\
\hline $22: 1 \mathrm{n}-9$ & 2.2 & 0.8 & 3.9 & 1.4 & 2.9 & 0.7 & 3.4 & 2.3 & 3.2 & 0.3 \\
\hline $24: 1 \mathrm{n}-9$ & 1.2 & 0.7 & 4.1 & 0.2 & 1.7 & 0.4 & 2.3 & 2.2 & 2.2 & 4.5 \\
\hline $18: 4 n-3$ & 2.8 & 0.2 & 0.4 & 0.2 & 0.5 & $\operatorname{tr}$ & 1.1 & 0.1 & 0.7 & 0.3 \\
\hline $20: 4 n-6$ & 0.5 & $\operatorname{tr}$ & 0.2 & $\operatorname{tr}$ & 0.5 & $\operatorname{tr}$ & 0.5 & $\operatorname{tr}$ & 0.5 & 0.1 \\
\hline $20: 5 n-3$ & 6.1 & 0.3 & 1.6 & 0.6 & 3.2 & 1.1 & 6.8 & 0.1 & 5.3 & 1.7 \\
\hline $22: 5 n-3$ & 1.2 & $\operatorname{tr}$ & 0.4 & $\operatorname{tr}$ & 1.4 & 1.8 & 1.1 & $\operatorname{tr}$ & 0.6 & $\operatorname{tr}$ \\
\hline $22: 6 n-3$ & 8.5 & 0.8 & 3.0 & 2.8 & 6.3 & 2.1 & 4.1 & 0.2 & 6.8 & 1.8 \\
\hline Others ${ }^{\mathrm{e}}$ & 9.3 & 12.2 & 5.6 & 9.1 & 6.8 & 10.3 & 8.0 & 12.9 & 7.4 & 13.8 \\
\hline Saturates & 15.4 & 57.6 & 18.3 & 48.0 & 12.0 & 38.8 & 12.6 & 41.9 & 12.2 & 45.4 \\
\hline Monoenes & 59.5 & 36.0 & 73.0 & 45.0 & 71.9 & 50.9 & 69.1 & 52.1 & 69.5 & 42.2 \\
\hline Polyenes & 24.2 & 3.6 & 7.8 & 4.8 & 15.1 & 8.2 & 16.9 & 2.5 & 17.4 & 9.9 \\
\hline Branched & 0.9 & 2.8 & 0.9 & 2.2 & 1.0 & 2.1 & 1.4 & 3.5 & 0.9 & 2.5 \\
\hline
\end{tabular}

a) Pooled samples $(\mathrm{n}=1)$.

b) Means $(n=5)$.

c) Pooled samples $(\mathrm{n}=14)$.

d) Pooled samples $(\mathrm{n}=5)$.

e) Consisted of 15:0, 17:0, 19:0, 20:0, 16:1n-11, 16:1n-5, 17:1n-8, 18:1n-11, 18:1n-5, 19:1n-8, 20:1n-7, $22: 1 n-7,16: 2 n-6,18: 2 n-6,18: 3 n-3,18: 3 n-9,20: 2 n-6,20: 3 n-6,20: 3 n-3,20: 4 n-3,21: 5 n-3,22: 4 n-6$,

22:5n-6, trimethyltridecane, I15:0, I16:0, A16:0, I17:0, A17:0, I18:0, and A18:0.

TG; triacylglycerol, PL; phospholipid, tr; trace (less than $0.05 \%$ ), I; iso, A; anteiso.

Of the C. pectoralis livers examined, the component fatty acids of TG were somewhat similar in composition to those of liver NL in the same teleost species previouly reported (15). That is, those in TG were rich in monoenes (the former: $69.5 \%$; the latter: $80.5 \%$ ) with $22: 1(21.4 \% ; 26.0 \%), 20: 1(16.0 \% ; 21.6 \%), 18: 1$ $(21.4 \% ; 20.6 \%)$ and $16: 1(7.9 \% ; 9.5 \%)$ acids, respectively. The ratios of monoenes to polyenes in the component fatty acids of TG in livers of the deep-sea teleost fish examined, $H$. johnsonii (9.4), C. acrolepis (4.8), C. cinereus (4.1) and C. pectoralis (4.0), were above 4.0, and were consistent with those $(4.1-51.0$; mean: 10.8$)$ in the liver NL of twenty-two species of the deep-sea teleost fish caught at depths of about 300-500 m (1517). It was suggested that this indicates a characteristic of fatty acid composition in TG and/or NL from livers of deep-sea teleost fish. The reason for this phenomenon appearing in the deep-sea teleost fish was dis- 


\section{K. Hayashi and H. Kishimura}

Table 3 Fatty Acid Composition of Triacylglycerols and Phospholipids in Flesh Lipids of Some Deep-sea Teleost Fish, Whiptails.

\begin{tabular}{|c|c|c|c|c|c|c|}
\hline & \multicolumn{2}{|c|}{$\begin{array}{l}\text { Roughscale rattail } \\
\text { Coryphaenoides } \\
\text { acrolepis }\end{array}$} & \multicolumn{2}{|c|}{$\begin{array}{l}\text { Pop-eye grenadier } \\
\text { C. cinereus }\end{array}$} & \multicolumn{2}{|c|}{$\begin{array}{l}\text { Pectoral rattail } \\
\text { C. pectoralis }\end{array}$} \\
\hline & $\mathrm{TG}^{\mathrm{a})}$ & $\mathrm{PL}^{\mathrm{a})}$ & $\mathrm{TG}^{\mathrm{b})}$ & $\mathrm{PL}^{\mathrm{b})}$ & $\mathrm{TG}^{\mathrm{a})}$ & $\mathrm{PL}^{\mathrm{a})}$ \\
\hline $14: 0$ & 2.6 & 0.6 & 2.9 & 1.0 & 2.6 & 1.0 \\
\hline $16: 0$ & 11.5 & 27.8 & 9.1 & 28.2 & 9.7 & 30.3 \\
\hline 18:0 & 2.9 & 6.6 & 2.1 & 6.7 & 1.9 & 5.7 \\
\hline $16: 1 n-9$ & 0.8 & 0.1 & 0.4 & 0.3 & 0.5 & 0.2 \\
\hline $16: 1 n-7$ & 5.0 & 1.2 & 7.7 & 2.2 & 7.9 & 2.0 \\
\hline $18: 1 n-9$ & 13.9 & 9.1 & 12.7 & 8.4 & 16.9 & 10.5 \\
\hline $18: 1 n-7$ & 3.8 & 3.0 & 5.2 & 3.3 & 4.3 & 3.4 \\
\hline $20: 1 n-11$ & 8.3 & 1.8 & 10.0 & 2.1 & 8.5 & 2.0 \\
\hline $20: 1 n-9$ & 5.1 & 1.9 & 5.1 & 1.3 & 6.4 & 2.4 \\
\hline $22: 1 n-11$ & 14.2 & 0.3 & 18.0 & 0.9 & 15.3 & 0.4 \\
\hline $22: 1 n-9$ & 1.8 & 0.1 & 2.8 & 0.3 & 2.6 & 0.1 \\
\hline $24: 1 n-9$ & 2.1 & 0.9 & 2.3 & 1.0 & 1.8 & 1.0 \\
\hline $18: 4 n-3$ & 0.5 & $\operatorname{tr}$ & 0.6 & 0.1 & 0.7 & 0.1 \\
\hline $20: 4 n-6$ & 1.0 & 3.0 & 0.8 & 2.6 & 0.5 & 1.5 \\
\hline $20: 5 n-3$ & 5.0 & 8.8 & 5.7 & 8.8 & 5.0 & 8.7 \\
\hline $22: 5 n-3$ & 1.7 & 1.7 & 1.1 & 2.2 & 0.5 & 1.0 \\
\hline $22: 6 n-3$ & 12.2 & 28.4 & 5.2 & 23.1 & 7.3 & 23.6 \\
\hline Others $^{\mathrm{c})}$ & 7.6 & 4.7 & 8.3 & 7.5 & 7.6 & 6.1 \\
\hline Saturates & 17.9 & 35.5 & 14.9 & 36.6 & 15.0 & 37.6 \\
\hline Monoenes & 56.7 & 19.4 & 67.0 & 22.4 & 66.3 & 23.8 \\
\hline Polyenes & 24.2 & 44.2 & 16.8 & 39.8 & 17.8 & 37.6 \\
\hline Branched & 1.2 & 0.9 & 1.3 & 1.2 & 0.9 & 1.0 \\
\hline
\end{tabular}

a) Pooled samples $(n=5)$.

b) Pooled samples ( $n=9)$.

c) See the footnote of Table 2 for e).

TG; triacylglycerol, PL; phospholipid, tr; trace (less than 0.05\%).

cussed somewhat (15-17). Namely, it seemed that the influence of phytoplanktons slightly affected deep-sea animals in the food chain, simultaneously with a decrease in the content of $20: 5 n-3$ and $22: 6 n-3$ acids corresponding to the $18: 3 n-3$ acid family originating in phytoplanktons throughout the food chain. It could be assumed that polyenes such as 20:5n-3 and 22:6n-3 acids from dietary intake of deep-sea teleost fish were not stored in the TG in the livers (Table 2) and were mainly transported to the flesh to construct PL in cell membrane, being necessarily composed of large amounts of 22:6n-3 and 20:5n-3 acids (Table 3).

In conclusion, the squalene levels $(0.79-1.76 \%)$ in liver lipids of $H$. johnsonii of the morid cods examined and $C$. cinereus, $C$. pectoralis and $C$. acrolepis in the whiptails examined were somewhat higher than those in olive oils $(0.15-0.73 \%)$ (27). The ratios of liver weight to body weight are normally high for $C$. pectoralis (5.4\%), C. acrolepis (4.3\%) and C. cinereus $(2.5 \%)$ among the whiptails examined, having advantageously large amounts of lipids in the livers, and the livers, discarded as waste, are therefore now an untouched resource of squalene as another replacement for shark liver oils and/or olive oil. Additionally, of the deep-sea teleost fish, liver lipids free of squalene, which contained large quantities of TG composed mainly of 
monoenoic fatty acids, are also important for industrial use in food processing hydrogenated fish oil, and are raw materials of margarine, fatspread and/or shortening.

\section{Acknowledgment}

We thank Ms. S. Oka of the Center for Instrumental Analysis, Hokkaido University, for technical assistance with GC-MS.

\section{References}

1. J.C. NEVENZEL, Biogenic Hydrocarbons of Marine Organisms, in Marine Biogenic Lipids, Fats, and Oils, Vol. I., (R.G. ACKMAN, ed.), CRC Press, Inc., Boca Raton, pp. 3-71 (1989).

2. M. TSUJIMOTO, A Highly Unsaturated Hydrocarbons in Shark Liver Oil, J. Ind. Eng. Chem., Vol. 8, 889-896 (1916).

3. Y. SHIMMA and H. SHIMMA, On Liver Oil of Deep-sea Sharks of Suruga Bay, Bull. Tokai. Reg. Fish. Res. Lab., No. 48, 53-61 (1966).

4. M. KAYAMA, Y. TSUCHIYA and J.C. NEVENZEL, The Hydrocarbons of Shark Liver Oil, Bull. Japan. Soc. Sci. Fish., Vol. 35, 653-664 (1969).

5. K. HAYASHI and T. TAKAGI, Distribution of Squalene and Diacyl Glyceryl Ethers in the Different Tissues of Deep-sea Shark Dalatias licha, Bull. Japan. Soc. Sci. Fish., Vol. 47, 281288 (1981).

6. D. PEYRONEL, J. ARTAUD, M.C. IATRIDES, P. RANCUREL and J.L. CHEVALIEL, Fatty Acid and Squalene Compositions of Mediterranean Centrophorus SPP Egg and Liver Oils in Relation to Age, Lipids, Vol. 19, 643-648 (1984).

7. P.P. DEPREZ, J.K. VOLKMAN and S.R. DAVENPORT, Squalene Content and Neutral Lipid Composition of Livers from Deep-sea Sharks Caught in Tasmanian Waters, Aust. J. Mar. Freshwater Res., Vol. 41, 375-387 (1990).

8. M.J. BAKES and P.D. NICHOLS, Lipid, Fatty Acid and Squalene Composition of Liver Oil from Six Species of Deep-sea Sharks Collected in Southern Australian Waters, Comp. Biochem. Physiol., Vol. 110B, 267-275 (1995).

9. C. BORCH-JENSEN, M.P. MAGNUSSEN and J. MOLLERUP, Capillary Supercritical Fluid Chromatographic Analysis of Shark Liver Oils, J. Am. Oil Chem. Soc., Vol. 74, 497-503 (1997).

10. H.M. STORM, S.Y. OH, B.F. KIMLER and S. NORTON, Radioprotection of Mice by Dietary Squalene, Lipids, Vol. 28, 555-559 (1993).

11. T.A. MIETTINEN and H. VANHANEN, Serum Concentration and Metabolism of Cholesterol During Rapeseed Oil and Squalene Feeding, Am. J. Clin. Nutr., Vol. 59, 356-363 (1994).

12. C.V. RAO, H.L. NEWMARK and B.S. REDDY, Chemopreventive Effect of Squalene on Colon Cancer, Carcinogenesis, Vol.
19, 287-290 (1998).

13. P. BONDIOLI, C. MARIANI, A. LANZANI, E. FEDELI and A. MULLER, Squalene Recovery from Olive Oil Deodorizer Distillates, J. Am. Oil Chem. Soc., Vol. 70, 763-766 (1993).

14. Y. YAMADA and K. HAYASHI, Fatty Acid Composition of Lipids from 22 Species of Fish and Mollusk, Bull. Japan. Soc. Sci. Fish., Vol. 41, 1143-1152 (1975).

15. K. HAYASHI and M. YAMADA, The Lipids of Marine Animals from Various Habitat Depths II. On the Fatty Acid Composition of the Neutral Lipids in Six Species of Gadiformes, Bull. Japan. Soc. Sci. Fish., Vol. 41, 1153-1160 (1975).

16. K. HAYASHI and M. YAMADA, The Lipids of Marine Animals from Various Habitat Depths III. On the Characteristics of the Component Fatty Acids in the Neutral Lipids of Deep-sea Fishes, Bull. Japan. Soc. Sci. Fish., Vol. 41, 1161-1175 (1975).

17. K. HAYASHI and M. YAMADA, The Lipids of Marine Animals from Various Habitat Depths IV. On the Fatty Acid Composition of the Neutral Lipids in Nine Species of Flatfishes, Bull. Fac. Fish. Hokkaido Univ., Vol. 26, 265-276 (1975).

18. E.G. BLIGH and W.J. DYER, A Rapid Method of Total Lipid Extraction and Purification, Can. J. Biochem. Physiol., Vol. 37, 911-917 (1959).

19. Y. ITABASHI and T. TAKAGI, Glass Capillary Gas Chromatography of Fatty Acids from Lipids of Marine Organisms, Yukagaku, Vol. 29, 855-865 (1980).

20. J.K.G. KRAMER, S.C. KUSHWAHA and M. KATES, Structure Determination of the Squalene, Dihydrosqualene and Tetrahydrosqualene in Halobacterium cutirubrum, Biochim. Biophys. Acta, Vol. 270, 103-110 (1970).

21. K. HAYASHI, Liquid Wax Esters in Liver Oils of the Deep-sea Teleost Fish Laemonema longipes, Nippon Suisan Gakkaishi, Vol. 53, 2263-2267 (1987).

22. K. HAYASHI and I. KASHIKI, Level and Composition of Wax Esters in the Different Tissues of Deep-sea Teleost Fish Laemonema longipes, Nippon Suisan Gakkaishi, Vol. 54, 135-140 (1988).

23. K. HAYASHI, K. HASEGAWA and H. KISHIMURA, Amount and Composition of Wax Esters in Various Tissue Lipids of Forked Hake Laemonema longipes, J. Oleo Sci., Vol. 51, 439445 (2002).

24. M.L. KARNOVSKY and W.S. RAPSON, South African Fish Products. Part XXVI. Application of the Fitelson Method of Squalene Determination to Some Marine Oils, J. Soc. Chem. Ind. London, Vol. 66, 124-125 (1947).

25. L.L. GERSHBEIN and E.J. SINGH, Hydrocarbons of Dogfish and Cod Livers and Herring Oil, J. Am. Oil Chem. Soc., Vol. 46, 554-557 (1969).

26. R.G. ACKMAN, R.F. ADDISON and C.A. EATON, Unusual Occurrence of Squalene in a Fish, the Eulachon, Thaleichthys pacificus, Nature, Vol. 220, 1033-1034 (1968).

27. W. DICKHART, The Squalene Contents of Various Oils, Amer. Jour. Pharm, Vol. 127, 359-361 (1955). 